\title{
A REVIEW OF THE TROPICAL DEVELOPMENT AND RESEARCH INSTITUTE'S CONTRIBUTION TO THE COCONUT INDUSTRY
}

\author{
by
}

\author{
D. ADAIR, J.H. BROADBENT, J.H.S. GREEN, A.D. MARTER
}

\section{INTRODUCTION}

The Tropical Development and Research Institute (TDRI) was formed on 1 April 1983 by the amalgamation of the Tropical Products Institute (TPI) and the Centre for Overseas Pest Research (COPR). The Institute has a long history of providing assistance and advice to developing countries in post-harvest aspects of food and other agricultural commodities, which include the many products dexived from the coconut. This review covers the Institute's work over the last ten years and illustrates the wide range of interests concerning coconuts. These cover research and development on dehusking and processing projects, economic studies for the establishment of new coconut-based industries, and technological improvements for the manufacture of charcoal from coconut shell.

Coconut producing countries are actively seeking ways of making the best use of the crop by utilising the whole nut - husk, shell, meat and water - and processing these materials into a variety of end products. Traditionally coir is produced from the husk, charcoal from the shell, oil from the dried meat and the cake produced after extracting the oil from copra is used as an animal feed material. Improved processing techniques, together with the possibility of establishing integrated processing facilities, offers the opportunity of producing a wider range of end-products frorn these basic materials, such as coconut crearn and desiccated coconut from fresh meat, activated carbon from shell charcoal, and fermented products frorn the water.

Considerable attention has been paid by the Institute to a balanced programme of assistance to the coconut industry, particularly in applying a level of technology appropriate for use in rural. areas. In this respect and in cooperation with a British engineering company, an expeller suitable for the smau-scale processing of copra has been developed for use in areas where the cost of transporting copra to central oil mills is high.

Procedures such as dehusking and the grating of fresh coconut meat for the domestic production of coconut cream and oil are traditionally carried out manually and involve intense physical labour. Prototype mechanical dehuskers have been constructed by the Institute's Industrial Engineering Department and, after trials in the UK, have been extensively tested under field conditions. However, a lower level of technology has been applied to improve the grating of fresh coconut fneat for coconut cream and oil for domestic use in order to reduce the physical effort which is -necessary for this operation and which is generally carried out by female members of a household. As part of the Institute's programme for assistance specifically to extension workers and other field staff in rural development, a stirrupoperated grater has been produced, which is a low cost piece of equipment which can be locally made, is simple to use and maintain.

Members of the Institute's staff, either singly or more often as a team consisting of an oilseed specialist, an economist and an engineer, have carried out techno-economic studies in coconutproducing countries in order to assess the possibilities of creating new coconut-based enterprises or up-dating existing industries. Such feasibility studies have been undertaken for the Overseas Development Administration, of which TDRI is a part, and for international Aid agencies such as the World Bank, UNIDO, FAO, LNCTAD, and the Asian Development Bank. 
In addition to consultancy assignments in countries where coconuts are of economic importance, TDRI has supplied personnel to the above mentioned organisations for producing development papers and manuals for the coconut industry, which have been influential in assisting policy decisions and practical improvements.

The various sectors of the coconut industry with which TDRI has been concerned are detailed in this, article.

\section{COCONUT DEHUSKING}

In the 1970s the Institute received numerous enquiries from the coconut industry authorities and coconut growers concerning sources of supply of mechanical coconut dehuskers. Investigation revealed that although various such machines have been described in the literature, and some patented, none had stood the test of the market place and remained in commercial. production.

There was, however, clearly a need for such a machine in two types of situation: that in which traditionally coconut has been dehusked manually using a spike but in which workers are no longer willing to undertake such work, and that in which the coconut industry is newly established and the age-old skills of manual dehusking are not available.

Accordingly TDRI decided to develop a dehusker and various new id,eas were examined. One of these resulted in the development of a new concept of blade system for dehusking and this was patented. Detailed testing of the system was undertaken in the UK using coconuts specially importedfrom Dominica for the purpose. The tests confirmed the effectiveness of the blade system, albeit a small beard remained attached to the nut. This beard can be removed in a secondary operation manually using a cutlass.

The work in the UK resulted in the production of a prototype machine which was subsequently subjected to field trials in several. coconut producing countries. In all trials indigenous coconuts were used as a raw material. These tests proved the technical feasibility of the mechanism and gave refiable data on the performance of the machine. They also indicated various ways in which future models might be improved. The British Technology Group (BTG) then negotiated a licence for commercial Production of the dehusker.

Despite the earlier positive results with the dehusking of traditional. varieties of coconuts, later work with hybrid coconuts has not been as effective. However, it may be possible to modify the existing design and produce a dehusker suitable for hybrid coconuts.

\section{COIR FIBRE}

At the request of the Government of Sri Lanka, the Institute fielded a team to carry out a study of the coir fibre industry with particular reference to the prospects for development and improvement of the operations therein. The study covered the potential for increasing the value added aspects of products, identification of potential areas for improvements in the processing methods and the R \& D needs of the industry. The report made a number of recommendations for action in all these areas; it placed particular emphasis on the need for short-term improvements in process methods in the industry.

Arising from this work the Institute formulated projects to investigate improvements to husk crushing methods before soaking, methods of making the operation of the defibring drums less unpleasant and safer, and methods of separation of fibre from coir dust at the point of production 
under the defibring; drums. The improvement to the operational environment on the defibring drum is of particular importance due to the fact that, because of the nature of the work as it now exists, men are becoming increasingly unwilling to perform this task. If this trend continues, serious constraints will. be imposed on production levels.

Design work for hardware to affect these improvements is substantially complete and manufacture of prototype equipment is underway. After proving trials in the UK have been completed using imported husks, field trials will be conducted in Sri Lanka. Given a successful completion of these, TDRI staff will liaise with the Coconut Development Authority (CDA) officers and local manufacturers to foster the production of the improved machines in Sri Lanka.

In recent years two research projects relating to coir have been undertaken in TDRI. Now concluded, both these projects had the objective of improving the competitiveness of coir products.

Coconut husks yield several types of fibre: brown bristle and mattress fibre are obtained from mature husks, and white or yam fibre is obtained from immature, green husks. Some bristle fibre is dyed black, and yarn fibre, used mainly for mats and matting, is dyed in a wide range of coloursbut must be bleached before dyeing in pastel shades. Largely traditional methods of dyeing are still widely used, with cheap dyes of poor fastness to light. Some traditional dyes are based on benzidine, a suspected carcinogen and restricted in some countnes, but still widely available. TDRI has recommended that since such dyes could contain free benzidine they should not be used unless the highest standards of industrial hygiene can be maintained. Acceptability of the dye in the intended market should also be verified.

An extended programme at TDRI involved use of alternative black dyes for bristle, the dyeing of bristle in colours, and the production of colours with improved fastness properties on yarn. A wide range of dyes and techniques was investigated in the laboratory. In addition, field trials were undertaken in Sri Lanka with the basic dye Synacril Black A which showed how practical difficulties can arise with the use of alternative dyes by the traditional black bristle fibre industry. A final report on the work has been published. (Canning and Jarman, 1985).

An investigation of a new approach to the flame-retardant treatment of coir has also been completed. Rubberised coir, formed by spray-bonding coir wiih natural rubber latex, is used to form cushioning pads for mattresses and upholstery, particularly for motor vehicle seating, and for heat and sound insulation in the construction industry. As a relatively inexpensive material, coir replaced animal hair in rubberised cushioning materials, but much of the market has since been lost to polyurethane foam, particularly in the automobile industry. The introduction of the American Motor Vehicle Safety Standard 303 specified a degree of flame-retardancy which posed a serio'us problem for the manufacture of rubberised coir seat components. Flame retardant processes were developed, but the resulting products were uncompetitive with polyurethane foam.

Work at TDRI, in collaboration with the Shirley Institute, Manchester, was initiated to develop a more economic process and led to a new approach: namely, application of flame retardant treatments to both the coir and latex binder (Holker and Jarman, 1979). Treatments using Amgard TR and Pryovatex CP, with modified treated latex binder were shown to be technically feasible.

Following laboratory work to determine optimum conditions for large scale application of Amgard TR to coir fibre, full-scale field trials were carried out in Sri Lanka in collaboration with a coir production and shipping company. The treated coir was shipped to Europe for evaluation in the manufacture of motor vehicle seat components. Rubberised coir made from this fibre satisfied the requirements of MVSS 303. There were problems with the vulcanization of the latex, but work at the Malaysian Rubber Producers Research Association has suggested a possible solution (Gazely, 
1982). The work makes possible a route to the successful competition of rubberised coir with polyurethane foam in the upholstery market (Baker, Bone and Edwards, 1982).

\section{COPRA PRODUCTION}

TDRI has extensive first hand experience of, and access to a wide range of information on dryers.employed in copra production. In recent years its role in this subject area has been mainly advisory, advice being given in response to specific enquiries received by post and during visits overseas.

In the past the Institute has participated in copra industry improvement schemes such as that undertaken in the Windward Islands in the early 1970s. In this, an officer appointed under UK Technical Co-operation was assigned for two years to undertake a programme of work on improvement of local copra dryers and drying practices. The Institute remains open to requests to undertake similar projects in the future. The work of such projects would usuafly be expected to include provision of guidance on local manufacture of dryer components, as well as provi'sion of advice on construction and operation of dryers of appropriate design.

Build-up of insect infestation in copra can be a serious problem in producing countries. When the copra is first produced infestation is low but it rapidly increases during storage under the humid tropical conditions of coconut producing countries, which are highly favourable for insect development. Not only do the insects damage the copra but they may cross-infest other commodities such as cocoa which is stored in the same area.

An example of this problem is that of the Solomon Islands where copra is accumulated in stores at locations throughout the islands to await shipment. Due to the irregularity of shipments copra may remain in store for many months allowing large infestations of insects to develop. The problem is exacerbated by the inadequacy of many of the stores which results in over-filling and poor protection from the elements.

A TDRI pest control specialist spent two months in the Solomon Islands during 1976 to train staff of the Ministry of Agriculture and Lands in the techniques of controlling insect infestation of copra. In particular staff were trained to furnigate copra with methyl bromide and phosphine and to handle and store copra so as to minimise potential damage due to insects. Recommendations were also made to avoid cross-infestation of other commodities being handled in the vicinity of copra. stores.

\section{DESICCATED COCONUT}

Desiccated Coconut (DC) is a food product derived from fresh coconut kernel, and extensively used in the confectionery and bakery industries for its unique flavour and textural characteristics. Manufactured exclusively in the coconut growing countries, the product reaches the world market in various forms ranging from the dried coconut particles, known as Fine and Medium Grade DC, to the dried slices and threads, known as Fancy-cut DC.

Desiccated coconut is primarily an export product, but the industry has grown considerably with annual exports of around 130,000 tons, worth about US\$140 x 106 to the producing countries. Although a number of countries throughout Asia and Africa manufacture DC, some $95 \%$ of the world's supply is produced by just two countries the Philippines and Sri Lanka.

During the past decade TDRI's involvement in this important foreign exchange eaming industry has been considerable. Specialist teams from TDRI, comprised of technologists and 
marketing economists, have carried out feasibility studies concemed with evaluating the viability of establishing new DC industries in Fiji, Tonga and the New Hebrides.

In 1977, at the request of the Govemment of Sri Lanka, a TDRI team visited the country to assess the potential for UK assistance to Sri Lanka's Coconut Industry. The TDRI team reviewed the structure of the Industry and identified the constraints preventing its further development. Subsequently, a strategy for improving the Industry was recommended which entailed changes in both technology and management.

In 1979, following approval by the Sri Lanka Government of the proposed strategy, a TDRI chernical engineer was seconded to the CDA to assist in implementing the changes recommended for the country's DC Industry.

Working in close coRaboration with technical staff drawn from the CDA's Development Division, the TDRI officer concentrated on developing procedures aimed at improving the overall quality of DC produced in Sri Lanka. The factors responsible for producing DC of poor bacteriological and organoleptic quality were first identified, and then measures were introduced to overcome existing problems. With regard. to the former, it was found that a number of factors encompassing both processing procedures and manufacturing plant were associated with producing DC of poor bacteriological quality. The routine cleaning methodology was, in general, suspect, as were the kernel sterilisation and disintegration operations. Improved sanitisation procedures, introduced during 1981, drarnatically improved this situation and, ultimately, led to the lowest-ever product rejections for bacteriological reasons recorded. by the Industry. Studies carried out on kernel sterilisation revealed the need for more effective sterilisation plant and led to the development of a new waterLwall steriliser. This steriliser overcame the problems inherent in the operation of the Industry's sterilisers and currently is in use in 12 of the country's DC mills.

Studies of the disintegrator confirmed its role as a major source'of cross-infection, due to the inability to open the machine for cleaning purposes. TDRI, in collaboration with the UK manufacturers of the disintegrator, have since redesigned the'unit to facilitate ease of cleaning and inspection. Research aimed at designing disintegrator rings for specific product grades is currently being carried out at TDRI's Industrial Development Department.

With regard to physical quality, discolouration during drying of the disintegrated kemel was established. as the major cause of product losses. It was further observed that the drying operation a critical step in the DC manufacturing process - had not been the subject of a detailed study. To remedy this gap, TDRI undertook a comprehensive study of the drying characteristics, of DC using both fixed and fluid. bed drying techniques. It was concluded from this study that fluid bed drying of DC offered potential advantages over existing systems in terins of hygiene and simplicity of operation. A fluid. bed dryer (FBD) was subsequently provided under UK Aid auspices and has since been installed and successfully commissioned by TDRI engineers in a Sri Lanka DC mill. Extended production trials on the FBD aimed at establishing its performance under typical working conditions are currently under way.

Apart from the work outlined above, on improving the overall quality of the DC produced in Sri Lanka, TDRI specialists completed an Energy Study for the DC Industry in 1981. This study, carried out in coUaboration with the CDA, entailed visiting DC mills to examine and evaluate the principal energy consurning operations of the DC manufacturing process. The methodology and energy consurned during the traditional on-site production of copra - produced as a by-product from reject nuts and parings - were also examined.

The overall fuel requirements of the DC Industry were assessed using data. obtained from both the measurements; made, and the questionnaire-surveys received from mill owners. The 
econornic viability of using alternative biornass resources available in the coconut growing and processing areas was evaluated. Detailed methods for saving fuel, which included modifications and redesign of furnaces, dryers and sterilisers, were recommended. Based on this study, the scope for application of a Waste Heat Recovery Carbonisation Unit in the Coconut Industry was identified and subsequently introduced in Sri Lanka.

The Institute has continued to make contributions to the improvement and expansion of the Desiccated Coconut Industry in 1984 and 1985 through work carried out for the Seychelles and Mozambique - concerned respectively with the possible establishment of a new and the renovation of an existing DC industry.

\section{COCONUT CREAM}

TDRI has undertaken extensive work on the wet processing of coconut kernel. Initially this was directed towards the production of coconut oil and edible by-products, and an efficient means of producing these was developed. Subtsequently, however, TDRI economists showed that the process was commercially uncompetitive with the established technology for producing oil with copra as an intermediary.

In the course of the work considerable insight had been gained into the wet milling of coconut kernel to maximise release of coconut crearn. This information was used as the basis for development of a number of methods for industrial production of coconut cream.

The new technology was field tested in Western Samoa in collaboration with a commercial company which was already engaged in the production of coconut crearn. On the basis of this testing, a prefeffed method of production was identified.

Subsequently TDRI undertook, on behalf of UNIDO, a study of the scope for coconut cream production in selected countries of the Asia/Pacific Region. The findings of the study have been published by UNIDO in report 10528 "The Industrial Production of Coconut Cream". The report also includes a description of the processes and equipment recommended by TDRI, and a financial analysis of the application of this process in the countries visited.

\section{COCONUT SHELL CHARCOAL}

Coconut shell charcoal is primarily used as the raw material in the manufacture of activated carbon where the micro-pore structure of the carbonised shell is particularly useful for gasphase filtration applications. No precise data are available on the worldwide production of activated carbon from the coconut shell but it is perhaps in the order of 40,000 tonnes annually, of which the Philippines and Japan account for 50\%, most of the remainder being produced by France, USA, India, Sri Lanka and the UK. International trade in coconut shell charcoal is normally 70,000 80,000 tonnes annually. The principal importers are Japan, France, the USA and the UK, the main origins being the Philippines and Sri Lanka.

In small scale batch carbonisation of charcoal, some $50 \%$ of the gross heat content is lost as waste heat. TDRI work on the introduction of improved charcoal production methods in developing countires (TDRI report RTG 12, 1980) led to the consideration of recovering the waste heat generated through the combustion of gases and tars evolved during the coconut shell carbonisation process. The evolution of obnoxious fumes duling the process has also resulted in banning or restricting (in Sri Lanka) the use of pits for making coconut shell charcoal, due to the proximity of humap habitation and environmental damage. In view of the above, inter alia, the Tropical Development and Research Institute developed a coconut shell carbonisation with waste heat 
recovery unit. The unit as developed virtually eliminates the obnoxious fumes emitted during the traditional method, simultaneously enabling the heat evolve, previously wasted during carbonisation, to be used through heat exchangers in associated processes - such as drying and sterilisation in the coconut industry. In addition, the gases evolved could be burned in furnaces/ boilers as a fossil fuel substitute or as a supplementary fuel.

A carbonisation with waste heat recovery unit was tested on a pilot plant in the UK using Jamaican coconut shells supplied by the Coconut Industries Board in Jamaica and the findings were published for the first time in TDRI report G127 in June 1979. Having shown that the technology was feasible, the unit was "scaled-up" to the prototype - details are given in TDRI report G 182 - and development work focussed on the application of the system in the coconut industry. A pre-production prototype was subsequently designed and manufactured in the UK and field tested in late 1983 at a desiccated coconut mill in Sri Lanka at the request of the Coconut Development Authority (CDA). The field trials showed that the unit as designed has a maximum capacity of 1.5 tonnes of dry coconut shell and yields 0.5 tonnes of saleable charcoal. The trials also showed the system, as operated, generates process heat equivalent to 190 litres of oil per 10 hour operation with the virtual elimination of obnoxious fumes emitted during the traditional process. A financial and economic evaluation of the system concluded that the adoption of the technology is an attractive commercial proposition. More over, the use of coconut shell a by-product of the industry instead of wood as a fuel source would reduce the pressure on an increasingly scarce resource. The scope for the application of the technology in copra drying and desiccated coconut production is being evaluated and funds have been allocated by the CDA for the manufacture of further units. As part of its on-going programme TDRI is continuing to give technical support to the industry in energy related matters and a "scaled-up" version of approximately twice the capacity of the initial unit is currently being designed.

There is clearly great scope for the application of the technology in coconut growing countries with attendant opportunities to save foreign exchange through substitution of imported fossil fuels. Moreover, by the export of coconut shell charcoal and activated carbon there are further opportunities to eam foreign excha nge. TDRI are therefore taking steps to promote the transfer of this technology with the view of maximising the utilisation of indigenous resources.

\section{COCONUT TRUNK}

TDRI transportable metal kilns - developed primarily for the conversion of timber to charcoal - have been used for the production of coconut shell charcoal of good quafity and yield.

The additional use of the kilns for coconut trunk charcoal production was investigated in Jamaica in 1978, as a means of disposing of palms recently killed by Lethal Yellow disease. Also in 1978, in Fiji, trials were carried out on small dry offcuts of palm from sawmill waste. A larger programme of work was undertaken in Thailand in 1984 as part of rehabilitation/plantation sanitation scheme where both fresh felled and partly seasoned trunk was successfufly carbonised using material from the top, middle, and base of the palm. A consumer acceptabillty/marketing trial of the charcoal produced was initiated and the carbonisation of palm butts in a local earth kiln was also demonstrated. As part of the work programme, laboratory studies on the quality of charcoal across and along the trunk have been carried out and preliminary trials on hand briquetting coconut palm charcoal have also been conducted. In general it has been concluded that carbonisation of coconut trunk can be carried out effectivelv using the transportable kiln.

In the energy study for the desiccated coconut industry carried out by TDRI with the CDA in Sri Lanka mentioned under Coconut Shell Charcoal the economics of using coconut trunks for charcoal production were considered, including the use of trunks for senescent palms cut down in 
proposed replanting programmes. The possibihty of using wood pellets was evaluated but found not to be as profitable as charcoal production or the direct use of wood as fuel in the immediate vicinity.

TDRI has undertaken a study of the pulping characteristics of coconut trunk and has reported the findings in Report L53. P. An earlier report (G43) related to studies of the production of particle board from coconut trunk. The Institute has also undertaken work on the use of coconut trunk as a constituent of wood wool/cement slabs. Findings indicated that these products afford only limited scope for industrial developments.

\section{ECONOMICS}

Work by TDRI's Marketing and Economics Departmentin the coconut sector has included market analyses and financial appraisals undertaken on a range of products and processing methods. Considerable inputs have been made in relation to wet processing, as inclicated under Coconut Cream. Work has also been. carried out on desiccated coconut, small scale copra crushing and fuel use of coconut husk and shell.

In relation to wet procesaing and coconut cream, work has been undertaken on the appraisal of alternative manufacturing processes in a selection of major coconut producing countries. These studies also included analysis of domestic market prospects, for both manufactured creams and traditional products. Addltionally, export market potential has been examined on a global basis covering coconut cream and associated products. The results highlighted the relatively limited prospects for coconut cream and associated products on international markets. However, in a number of major coconut producing countries a viable manufacturing process was identified with potential for marketing coconut cream domestically in urban areas.

Work on desiccated coconut has primaril y involved the analysis of export market potential, with an evaluation of major markets at the global level. International demand for desiccated coconut was found to be relatively static but some potential for new suppliers was identified in the context of considerable fluctuations in production and export availability from established supplying countries.

A study has been carried out on the feasibility of utilising coconut husk and shell as a fuel source to supply energy needs in copra crushing. For the specific location examined the proposal was found to be f-mancially unviable, principally because of the differential in transportation costs between supplying whole nuts, as opposed to copra, to the factory site.

Small scale copra crushing is a topic of current interest with work planned on a financial analysis of proposed technology, in association with local marketing of the derived oil.

\section{TRAINING}

An important function of TDRI is to offer training to overseas personnel in aspects of post-harvest technology and. generany this takes the form of individual training tailored to the needs of the trainee. However, TDRI also has facilities for training groups of personnel and staff who can undertake on-the-spot training in overseas countries.

The training courses in coconut technology organised by TDRI involve the edible oils and oilseed laboratory in London and. the industrial Development Department at Culham, near Oxford where appropriate arrangements are made for trainees to gain further experience with other private and industrial organisations. 


\section{CONCLUSION}

There has been long standing co-operation between TDRI and the many government organisations, research institutes and industries concerned with the various aspects of coconut tech nology in developing countries. The coconut industry is wides pread throughout the tropics and has important social implications with regard to employment and rural development as the crop is mainly grown by smallholders. One of the principal objectives of TDRI has been to encourage processing and improvements to the post-harvest utilisation of coconuts in the producing countries and to assist in creating means of establishing agro-industries in rural areas. In this respect, during 1986 the Institute, with funding by UNIDO will be undertaking field trials in a Pacific island with a small oilseed expeller which is suitable for the rural processing of copra. This expeller is manufactured by a major UK engineering group. The Pacific region is an important coconut producing area but suffers from poor and high cost transport facilities resulting in the under utilisation of the coconut crop.

This article has outlined the Institute's contribution to the coconut industry and the continuing policy of offering technological assistance in order to improve the overall benefits which can be derived from the coconut crop at the rural and industrial level. The commitment to the application of appropriate technology should become apprarent in the next decade.

\section{ACKNOWLEDGEMENTS}

The authors wish to thank their Institute colleagues who assisted with. this review and particularly those of the Industrial Development Department. 


\section{REFERENCES}

Baker, D. M., Bone., R. J. and Edwards, Muriel (1982). Flame retarded rubberised coir developments and prospects, for wider upholstery use. Trop. Sci. 24, 1-37 - 252.

Canning, A. J. and Jarman. C. G. (1985). Improvements to the dyeing of coconut fibre (coir). Drop. Sci. 25, 91-102.

Gazely, K. F. (1982). The effect of ammonium polyphosphate on latex compounds for coin Trop. Sci. 24, 253 - 259.

Holker, J. R. and Jarman, C. G. (1979). Plast. rubber mater. appl., pp 129 - 131.

Adair, D. and Marter, A. D. (1982) The industrial production of coconut cream. UNIDO Report 10528. Vienna: United Nations Industrial Development Organisation.

Paddon, A. R. and Harker, A. P. (1 980). Charcoal production using a transportable metal kiln. TDRI Rural Technology Guide No. 12 London: Tropical Development and Research Institute.

Breag, G. E. and Harker, A. P. (1979). The utilisation of waste heat produced dunng the manufacture of coconut shell charcoal for the centralised production of copra. TDRI Report G127. London: Tropical Development and Research Institute.

Breag, G. E., Parker, A. P., Paddon, A.R. and Robinson, A. P. The design, construction and operation of a unit for the carbonisation of coconut shell with recovery of waste heat. TDRI Report G182. London: Tropical Development and Research Institute.

Palmer, E. R. and Gibbs, J. A. (1979). Pulping trials on the wood from the trunk of coconut (Cocos nucifera). TDRI Report L53. London: Tropical Development and Research Institute.

Chittenden, A. E., Flaws, L. J. and Hawkes, A. T. (1969) Particle boards from coconut palm timber. TDRI Report G43. London: Tropical Development and Research Institute. 